\title{
Impact of Concentration and Foliar Spraying Times Number with Boron on Pomegranate Fruit Cracking
}

\author{
1*Dr. Rida DRAIE; ${ }^{2}$ Ali ABORAS \\ ${ }^{1}$ Faculty of Agricultural Engineering, University of Idlib, Syria \\ ${ }^{2}$ Postgraduate Student, MA, Faculty of Agricultural Engineering, University of Idlib, Syria \\ *Corresponding Author Email: ridadraie@hotmail.com
}

\begin{abstract}
The research was carried out in the 2018 agricultural season with the aim of studying the effect of boron foliar spray on reducing cracking of the French pomegranate variety. The experiment was conducted according to a completely randomized design (CRD). We had three treatments for boron concentrations $(0,100,200$ ppm) and four treatments for the number of spraying times $(0,1,2$, and 3$)$. The results showed the superiority of all spraying treatments with boron over the control treatment in most of the studied traits. The increase in the spraying concentration also achieved a significant reduction in the percentage of fruit cracking, which amounted to $21.63 \%$ and $18.50 \%$ in the treatment of concentration of 100 and $200 \mathrm{ppm}$, respectively. The increase in the number of spraying with boron led to a decrease in the percentage of fruit cracking, which amounted to $26.83 \%, 19.89 \%$, and $16.28 \%$ for 1,2 , and 3 spraying times respectively. While the percentage of fruit cracking in the control was $73.96 \%$.
\end{abstract}

Keywords: Boron, Foliar Spraying, Concentration, Number of Spraying Times, Pomegranate Fruit Cracking.

\section{INTRODUCTION}

The fruit cracking is one of the most important physiological diseases affecting pomegranate fruits (Malhotra et al., 1983). Where Panwar et al. (1994) and Singh (1995) showed that when the fruits crack, they are vulnerable to infection with bacteria and fungi, and thus lose their marketing value and may become unfit for human consumption, causing a very large economic loss for pomegranate farmers (Finkel and Holbrook, 2000; Schrader et al., 2002). Singh et al. (2006) and Bankar and Prasad (1992) confirmed that about 25$40 \%$ of the fruits crack at the time of ripeness, and these fruits lose their quality, become unfit for marketing, and thus cause a great loss in production. The crack rate varies between 10$70 \%$ depending on climatic conditions (Anonymous, 1983). Draie and Aboras (2021a; 2021b) indicated that the rate of cracking reach $74 \%$, which leads to reluctance to reap the fruits in the years of severe injury. El-Sayed et al. (2014) stated that the percentage of economic damage caused by the cracking reaches more than 50\%. While Pal et al. (2017) stated that the economic loss resulting from the cracking ranges between $10-40 \%$ on average and sometimes it reaches $70 \%$.The cracking percentage varies in general according to the varieties, so in the early ripening varieties, it is about $34 \%$ and it reaches 63\% in the late maturing varieties (Pant, 1976). The degree of cracking also varies according to the stages of fruit growth, so cracking is clearer in the stage of ripening fruits (Hoda and Hoda, 2013; Shulman et al., 1984; Yazici and Kaynak, 2006).

The cause of cracking of pomegranate fruits is mainly due to many factors, the most important of which are genetics (variety), environmental factors, and various agricultural treatments (Saad et al., 1988; Prasad et al., 2003; Chandra et al., 2011; Khadivi-Khub, 2014). Abd and Rahman (2010) showed that fruit cracking is associated with higher temperatures, higher transpiration, lower humidity in the air and soil, and sharp fluctuations in temperature between day and night during fruit growth. The association of fruit cracking of pomegranate with nutrient deficiency and irregular irrigation has also been indicated (Gharesheikhbayat, 2006; Khalil and Aly, 2013; Saei et al., 2014; Galindo et al., 2014).

Khan et al. (1974) confirmed that deficiency of some nutrients such as boron and zinc leads to fruit cracking. The cracking of pomegranate fruits is directly related to nutritional deficiencies, especially boron, calcium, zinc and potassium (Gharesheikhbayat, 2006; Saei et al., 2014). Whereas Singh et al. (1967) explained that cracking in fruits can be caused mainly by the deficiency of boron.Singh, (1980) stated that the fruit cracking of pomegranate is due to the dry skin of the outer surface of the fruit during periods of drought following the rains, with a lack of boron responsible for the cracking.Dube and Ram (1970) assert that the deficiency of boron causes the fruits to crack. Also, Pant (1976) indicated in his study on the Judipuri pomegranate variety, and Singh et al. (1967) that the cracking in the immature fruits of pomegranate occurs due to boron deficiency because the elasticity of cell walls is controlled by this element.

Abdel-Aziz et al. (2001) showed that four times spraying the pomegranate trees with boric acid individually led to a 
ISSN (online): 2581-3048

reduction in the percentage of cracked fruits. Kuldeep-Khatri et al. (2001) confirmed that spraying pomegranate trees (variety Jodhpur Red), after 15 and 30 days of fruit-set, with boron at a concentration of $0.2 \%$ led to a significant reduction in the percentage of fruit cracking. Khan et al. (1974) emphasized the necessity of spraying with zinc sulfate and boric acid in two concentrations $(0.2$ and $0.4 \%)$ to prevent cracking of the fruits of the Rose Scented pomegranate variety.

Pomegranate is grown well in Syria, which the production covers the local market with only a small portion being exported. However, pomegranate cultivation in Syria is exposed to many problems that affect the quantity and quality of production, the most important of which is the problem of fruit cracking, in which the severity of infection related to the varieties. The French variety is one of the most important cultivated varieties in northern Syria, in terms of cultivated area and in terms of local demand. However, due to the sensitivity of this variety to the fruit cracking, the areas cultivated with it began to decrease and to move towards the cultivation of other crops. Accordingly, a number of studies have been conducted (including this research) with the aim of studying the effect of foliar spraying with the boron (different concentrations and a different number of spraying times) on the possibility of reducing the fruit cracking of this variety.

\section{MATERIALS AND METHODS}

\subsection{Experimental Location}

This research was conducted in 2018 in an orchard planted with pomegranate trees in the city of Sarmada, which is located on the Syrian-Turkish border. The city of Sarmada is about $40 \mathrm{~km}$ to the north of Idlib, and it is approximately 383 meters high. The total rainfall during the research season was $693 \mathrm{~mm}$. The average minimum temperatures for the coldest month were $2^{\circ} \mathrm{C}$, and the average maximum temperatures for the warmest month were $35^{\circ} \mathrm{C}$.

\subsection{Plant Materials}

The experiment was carried out on French pomegranate trees, which have large, spherical to flattened fruits, with red skin and long necks. The seeds are surrounded by a bloody red pulp, the leaf is elongated, and the branches are spiny. The fruits of this variety are prone to cracking (Draie and Aboras, 2021a; 2021b).

\subsection{Experimental Design and treatments}

The experiment was performed in the 2018agricultural season in a field planted with French pomegranate trees at the age of 10 years and dimensions $4 \times 4 \mathrm{~m}$. The complete randomized design (CRD) was used.
The trial included three treatments for the concentrations of boron and four treatments for the number of foliar spraying times with boron, according to the following:

Boron solution concentrations: 0, $100 \mathrm{ppm}(\mathrm{A})$, and 200 ppm (B).

$>$ Number of foliar spraying times: 0, 1, 2, and 3 times:

- Control without spraying.

- Foliar spraying once after the beginning of flowering (1/5/2019).

- Foliar spraying twice after the beginning of flowering (1/5/2019) and after the completion of the fruit set (1/6/2019).

- Foliar spraying three times after the beginning of flowering (1/5/2019), after the completion of the fruit contract (1/6/2019), and when the fruits start to color $(1 / 7 / 2019)$.

Five replicates per treatment, with one tree (French pomegranate variety) per replicate, were adopted. Consequently, the number of pomegranate trees used in the experimentation $=3$ concentrations $\mathrm{x} 4$ foliar spraying times $\mathrm{x}$ 5 replicates $\mathrm{x} 1$ tree $=60$ trees.

\subsection{Measured Parameters}

The following measurements were taken:

\section{Flowering traits:}

- Number of days until the starting of flowering.

- Number of total flowers.

- Number of hermaphrodite flowers.

- Ratio of hermaphroditic flowers (\%).

\section{Fruits-set and Yield characteristics:}

- Ratio of fruit-set (\%).

- Number of days until the date of fruits ripening.

- Productivity kg/tree.

\section{Physical properties of fruits:}

- Ratio of cracked fruits per tree (\%).

- Diameter of fruit (cm).

- Weight of fruits $(\mathrm{kg})$.

- Weight of fruit peels $(\mathrm{g})$.

- Internal tissue weight (g).

- Weight of seeds (g).

- Weight of juice $(\mathrm{g})$.

\section{Fruit quality characteristics:}

- Ratio of juice (\%).

- Total Soluble Solids (T.S.S.\%). 
ISSN (online): 2581-3048

- Acidity of juice (pH).

\subsection{Statistical analysis}

The results were analyzed by the statistical program (GenStat-12). The averages were compared by calculating the LSD at the level of significance $(5 \%)$.

\section{RESULTS AND DISCUSSION}

\subsection{Effect of spraying concentration with boron on the studied characteristics}

Table 1: Effect of spraying concentration with boron on the studied characteristics

\begin{tabular}{|l|c|c|c|c|}
\hline Trait & 0 & 100 & 200 & LSD $_{5 \%}$ \\
\hline Flowering & 52.00 & 50.30 & 48.75 & 0.10 \\
\hline Ripening & 151.00 & 146.25 & 143.10 & 0.32 \\
\hline Number of total flowers & 287.33 & 473.20 & 516.49 & 3.87 \\
\hline Hermaphrodite flowers (\%) & 25.75 & 40.87 & 42.44 & 0.46 \\
\hline Fruit-set (\%) & 21.62 & 44.65 & 49.62 & 1.08 \\
\hline Diameter of fruit (cm) & 8.32 & 11.52 & 11.98 & 0.14 \\
\hline Weight of fruits (g) & 256.12 & 368.12 & 404.02 & 1.63 \\
\hline Weight of fruit peel (g) & 60.99 & 79.36 & 83.45 & 0.68 \\
\hline Internal tissues weight (g) & 59.12 & 74.53 & 81.47 & 1.44 \\
\hline Weight of seeds (g) & 136.01 & 214.23 & 239.10 & 1.46 \\
\hline Ratio of juice (\%) & 27.32 & 39.51 & 40.63 & 0.13 \\
\hline Acidity of juice (pH) & 2.98 & 3.37 & 3.47 & 0.02 \\
\hline $\begin{array}{l}\text { Total Soluble Solids } \\
\text { (T.S.S. \%) }\end{array}$ & 15.22 & 16.15 & 17.06 & 0.08 \\
\hline Productivity/tree (kg) & 11.36 & 15.96 & 18.39 & 1.20 \\
\hline
\end{tabular}

All foliar spraying concentrations with boron significantly exceeded the control in the number of days required to reach flowering (the value in control was 52.00 days). The treatment of concentration B (200 ppm) by 48.75 days outperformed the treatment of concentration A (100 ppm) by 50.30 days in the mentioned characteristic. The foliar spraying concentrations outperformed the control in reaching the ripeness of the fruits, as the control needed 151 days, and the increase in the concentration led to significant differences between the spraying treatments themselves, as the treatment of concentration B outperformed the control by 143.10 days over the treatment of concentration A by 146.25 days (Table 1).

From Table (1) it appears that the total number of flowers in the control reached 287.33, $25.75 \%$ of them were hermaphrodites. The treatment of concentration A achieved a significant difference over the control in the characteristic of the total number of flowers, which amounted to 473.20 flowers, also it was superior in the percentage of hermaphroditic flowers, which amounted to $40.87 \%$. While the treatment of concentration $B$ achieved a significant difference from concentration $\mathrm{A}$, with the total number of flowers 516.49, and by the percentage of hermaphrodite flowers which amounted to $42.44 \%$. As for the fruit-set, it reached $21.62 \%$ in the control, $44.65 \%$ in treatment of concentration A, and $49.62 \%$ in treatment of concentration B, and the differences were significant between all treatments (Table 1).

Foliar spraying with boron also had a significant effect on the weight and diameter of the pomegranate fruit, as the weight of the fruit in the control reached $256.12 \mathrm{~g}$ and its diameter was $8.32 \mathrm{~cm}$. The treatment of concentration $\mathrm{A}$ achieved a significant difference on the control with a fruit weight and diameter of $368.12 \mathrm{~g}, 11.52 \mathrm{~cm}$ respectively. The treatment of concentration $\mathrm{B}$ achieved a significant difference from the treatment of concentration $\mathrm{A}$, as the weight of the fruit in it was $404.02 \mathrm{~g}$ and the diameter of the fruit was 11.98 $\mathrm{cm}$ (Table 1).

Table (1) shows the significant effect of the concentrations used in the weight of the peel and the weight of the internal tissues of the fruit, as their weight in the control reached $60.99 \mathrm{~g}$ and $59.12 \mathrm{~g}$, respectively. The treatments of concentration A and B achieved a significant difference from the control, so the peel weight was $79.36 \mathrm{~g}$ and the internal tissue weight was $74.53 \mathrm{~g}$ in the treatment of concentration A, the weight of the peel was $83.45 \mathrm{~g}$ and the internal tissue weight was $81.47 \mathrm{~g}$ in the treatment of concentration $\mathrm{B}$, with a significant superiority of concentration B over treatment of concentration A. Also, the weight of the seeds increased due to the effect of foliar spraying with boron, reaching $136.01 \mathrm{~g}$, $214.23 \mathrm{~g}$, and $239.10 \mathrm{~g}$ in the control and in the treatments of concentration $\mathrm{A}$, and concentration $\mathrm{B}$, respectively (Table 1).

All spraying concentrations with boron exceeded the treatment of the control in terms of the percentage of juice, which amounted to $27.32 \%$ (in the control). The treatment of concentration B outperformed the treatment of concentration A with ratio of $40.63 \%$ and $39.51 \%$, respectively, (Table 1). The $\mathrm{pH}$ (acidity) value increased with the effect of boron foliar spraying, reaching 2.98 in the control, 3.37in the treatment of concentration $\mathrm{A}$, and 3.47in the treatment of concentration $\mathrm{B}$, and the differences were significant between all treatments. Also, the percentage of total soluble solid (T.S.S.) increased due to the effect of foliar spraying with boron, reaching $15.22 \%$ in the control. Significantly, all the treatments outperformed the control, as the T.S.S. percentage in the treatment of concentration $\mathrm{B}$ reached $17.06 \%$, and it was superior to the treatment of concentration $\mathrm{A}$, in which the T.S.S. percentage was $16.15 \%$ (Table 1).

Table (1) also indicates the significant effect of spraying with boron on the productivity of the French pomegranate variety, as the yield in the control reached $11.36 \mathrm{~kg} /$ tree. The treatment of concentration A achieved a significant increase over the control, with a yield of $15.96 \mathrm{~kg} /$ tree. The treatment of concentration $\mathrm{B}$ achieved a significant increase over the treatment of concentration A, with a productivity of 18.39 $\mathrm{kg} / \mathrm{tree}$. The differences were significant between all 
ISSN (online): 2581-3048

treatments. Consequently, the spraying treatments achieved an increase in productivity over the control by $140.49 \%$ and $161.88 \%$ in the treatments of concentration $\mathrm{A}$ and $\mathrm{B}$, respectively.

Our study was in agreement with Shaheen (1995), which reached an increase in the percentage of hermaphroditic flowers in pomegranate by increasing the concentration of the spraying substance. Perica et al. (2001) confirmed that when increasing the concentration of spraying trees with boron at a concentration of 246-491 ppm, this led to a significant increase in the percentage of fruit-set. Al-Imam and AlBrifkany (2010) sprayed trees with four concentrations of boron $(0,50,100$, and $150 \mathrm{ppm})$, this resulted in a significant increase in the percentage of fruit-set. Fayed (2010), showed the superiority of all spraying treatments of Manfaloutipomegranate variety over the control, and that the increase in the spraying concentration from $700 \mathrm{ppm}$ to 1000 ppm, this led to a significant increase in the percentage of juice in the fruit. These results also agree with Arora and Singh (1972) where confirmed an increase in the length and diameter of the fruit and an increase in the T.S.S. when increasing the spraying concentration with boron to the concentration of $170 \mathrm{ppm}$. Abdel-Aziz et al. (2001) mentioned that foliar spraying of Manfaloutipomegranate variety with the following boron concentrations (42.5, 85, and $170 \mathrm{ppm})$, which caused an increase in the number of fruits and the total yield of trees.

\subsection{Effect of spraying times with boron on the studied characteristics}

Table 2: Effect of spraying times with boron on the studied characteristics

\begin{tabular}{|l|c|c|c|c|c|}
\hline Trait & 0 & 1 & 2 & 3 & LSD $_{5 \%}$ \\
\hline Flowering & 52.00 & 51.00 & 50.00 & 48.80 & 0.09 \\
\hline Ripening & 151.00 & 147.50 & 146.00 & 144.25 & 0.18 \\
\hline $\begin{array}{l}\text { Number of total } \\
\text { flowers }\end{array}$ & 287.33 & 424.95 & 471.15 & 513.32 & 3.13 \\
\hline $\begin{array}{l}\text { Hermaphrodite } \\
\text { flowers (\%) }\end{array}$ & 25.75 & 40.27 & 40.69 & 42.31 & 0.42 \\
\hline Fruit-set (\%) & 21.62 & 45.06 & 46.56 & 47.80 & 1.04 \\
\hline $\begin{array}{l}\text { Diameter of fruit } \\
\text { (cm) }\end{array}$ & 8.32 & 11.39 & 11.54 & 11.88 & 0.11 \\
\hline Weight of fruits (g) & 256.12 & 348.95 & 376.30 & 399.74 & 3.22 \\
\hline $\begin{array}{l}\text { Weight of fruit peel } \\
\text { (g) }\end{array}$ & 60.99 & 77.42 & 79.35 & 81.60 & 1.13 \\
\hline $\begin{array}{l}\text { Internal tissues } \\
\text { weight (g) }\end{array}$ & 59.12 & 68.63 & 74.89 & 79.94 & 0.77 \\
\hline Weight of seeds (g) & 136.01 & 202.90 & 222.06 & 238.20 & 1.35 \\
\hline Ratio of juice (\%) & 27.32 & 39.71 & 40.49 & 41.23 & 0.25 \\
\hline Acidity of juice (pH) & 2.98 & 3.31 & 3.37 & 3.46 & 0.01 \\
\hline $\begin{array}{l}\text { Total Soluble Solids } \\
\text { (T.S.S.\%) }\end{array}$ & 15.22 & 15.86 & 16.54 & 17.24 & 0.14 \\
\hline $\begin{array}{l}\text { Productivity/tree } \\
\text { (kg) }\end{array}$ & 11.36 & 15.14 & 16.98 & 18.17 & 1.01 \\
\hline
\end{tabular}

It is evident from Table (2) the superiority of all spraying treatments over the control in the number of days required to reach the flowering stage (where the value in the control was 52.00 days). The increase in the number of spraying times had a positive effect in this aspect, as the three-time spraying were 48.80 days more than the twice spraying by 50.00 days, which outperformed the once spraying by 51.00 days. Table (2) also shows the significant effect of increasing the number of spraying times to reach the stage of fruit ripeness, as all treatments significantly outperformed the control treatment, which required 151 days. The three-time spraying treatment (by 144.25 days) outperformed the twice spraying treatment (by 146.00 days), which outperformed the once spraying treatment (by 147.00 days).

Also, the increase in the number of spraying with boron had a significant effect in increasing the number of total flowers and the percentage of hermaphroditic flowers. The total number of flowers in the control reached 287.33, of which $25.75 \%$ were hermaphrodites. The once spraying treatment achieved a significant superiority over the control treatment, with a total of 424.95 flowers, of which $40.27 \%$ were hermaphrodites. The treatment of the twice spraying achieved a significant superiority over the treatment of once spraying, and the number of flowers in it was 471.15 , of which $40.69 \%$ were hermaphrodites. While the treatment of the three-time spraying outperformed all the treatments, with a total number of flowers 513.32, of which $42.31 \%$ were hermaphrodites (Table 2).Spraying and increasing the number of spraying times had a significant effect on the percentage of fruit-set, as the ratios reached $21.62 \%, 45.06 \%, 46.56 \%$, $47.80 \%$, in the control, and in the treatments of once, twice, and three-time spraying, respectively. The differences were significant between all treatments (Table 2).

The increase in the number of spraying times also had a significant effect on increasing the weight and diameter of the fruit, as the weight of the fruit in the control reached $256.12 \mathrm{~g}$ and its diameter was $8.32 \mathrm{~cm}$. the treatment of once spraying led to a significant difference above the control, with a weight of fruit of $348.95 \mathrm{~g}$ and diameter of the fruit of $11.39 \mathrm{~cm}$. The treatment of twice spraying achieved a significant difference compared to the treatment of once spraying, with a weight of fruit of $376.30 \mathrm{~g}$ and diameter of fruit of $54.11 \mathrm{~cm}$. The treatment of three-time spraying achieved a significant difference from the twice spraying, with a weight of fruit of $399.94 \mathrm{~g}$ and diameter of fruit of $11.88 \mathrm{~cm}$ (Table 2).

Table (2) shows the significant effect of increasing the number of spraying times on the weight of the peel and the weight of the internal tissues of the fruit, as their weight in control reached $60.99 \mathrm{~g}$ and $59.12 \mathrm{~g}$, respectively. The weight of the peel was $81.60 \mathrm{~g}$ and the internal tissue weight was $79.94 \mathrm{~g}$ in the three-time spraying treatment. Whereas, in the treatment of twice spraying, the weight of the peel was $79.35 \mathrm{~g}$ and the weight of the internal tissues was $74.89 \mathrm{~g}$. As for the 
ISSN (online): 2581-3048

treatment of once spraying, the weight of the peel was $77.42 \mathrm{~g}$ and the weight of the internal tissues was $68.63 \mathrm{~g}$. Therefore, the differences were significant between all transactions. Table (2) shows the significant positive effect of increasing the number of spraying times on increasing the seed weight, compared to the control in which the seed weight was 136.01g. The treatment of once spraying outperformed the control, with a seed weight of $202.90 \mathrm{~g}$. The treatment of twice spraying also achieved a significant increase over the treatment of once spraying, with a seed weight of $222.06 \mathrm{~g}$. The treatment of three-time spraying achieved a significant increase over the treatment of the twice spraying and outperformed all treatments, with a seed weight of $238.20 \mathrm{~g}$.

Table (2) also shows the significant effect of spraying and increasing the number of spraying times in the ratio of juice, as the percentage in the treatments reached $27.32 \%, 39.71 \%$, $40.49 \%$, and $41.23 \%$ in the control, and in the treatments of once, twice, and three-time spraying, respectively. The treatment of three-time spraying outperformed all the treatments, and the differences were significant between all of them. The increase in the number of foliar spraying with boron resulted in an increase in the $\mathrm{pH}$ (acidity), reaching 2.98 in the control. The treatment of once spraying significantly exceeded the control, with a $\mathrm{pH}$ of 3.31. Also, the treatment of twice spraying outperformed the treatment of once spraying, with a $\mathrm{pH}$ of 3.37. The treatment of three-time spraying outperformed all treatments, with a $\mathrm{pH}$ of 3.46 (Table 2). Also, the percentage of T.S.S. increased due to the effect of foliar spraying with boron, as its value in the control reached $15.22 \%$. All the treatments were significantly superior to the treatment of the control, as the T.S.S. in the treatment of threetime spraying reached $17.24 \%$. It significantly outperformed the treatment of twice spraying, in which the T.S.S. was $16.54 \%$, which was significantly superior to the treatment of once spraying, in which the T.S.S. reached $15.86 \%$ (Table 2).

Table (2) indicates the significant effect of increasing the number of spraying with boron on the productivity of the French pomegranate variety, as the productivity in the control reached $11.36 \mathrm{~kg} /$ tree. The treatment of once spraying achieved a significant increase over the control, with a productivity of $15.14 \mathrm{~kg} /$ tree. The treatment twice spraying achieved a significant superiority over the treatment of once spraying, with a productivity of $16.98 \mathrm{~kg} /$ tree. While the treatment of the three-time spraying significantly outperformed all treatments, their productivity reached 18.17 $\mathrm{kg} /$ tree. The spraying treatments achieved an increase in the productivity over the control by $133.27 \%, 149.47 \%$, and $159.95 \%$ in the treatments of once, twice and three-time spraying, respectively.

Our study is consistent with Michra and Khan (1981) where confirmed that spraying with boron alone or in combination with zinc increased the size, weight, length and diameter of pomegranate fruits. Abdel-Aziz et al. (2001) showed that fertilizing pomegranate trees with boron alone or in combination with calcium and potassium led to the improvement of the physical and chemical properties of the fruits. Vossen and Daevarenne (2006) indicated that increasing the number of foliar spraying with boron four times, led to an increase in the weight of the wet fruit and the pulp. El-khawaga (2007) confirmed that foliar fertilization of pomegranate trees, boron $0.2 \%$ separately or in combination with iron $0.4 \%$, manganese $0.3 \%$, and zinc $0.3 \%$, led to a significant increase in the number of fruits and in production. Bambal et al. (1991) showed that foliar fertilization of Ganesh pomegranate variety with some micro-elements such as boron, zinc and iron, led to an increase in production. These results are also consistent with Wojcik et al. (1999) where added boron to the soil and sprayed the leaves several times and at different dates, the results showed an increase in the percentage of fruit-set and in the total productivity per tree.

\subsection{Effect of interaction between the spraying concentrations and spraying times with boron on the studied characteristics}

The interaction between the concentrations of spraying with boron (concentration $100 \mathrm{mg} / \mathrm{L}$, and the concentration $200 \mathrm{mg} / \mathrm{L}$ ) and the number of spraying times with boron (spraying once, spraying twice, and spraying three times) had a significant effect on the whole studied characteristics compared with the control (Table 3).

Table 3: Effect of interaction of the spraying concentrations and spraying times with boron

\begin{tabular}{|c|c|c|c|c|c|c|c|c|c|}
\hline $\begin{array}{l}\text { Spraying } \\
\text { times }\end{array}$ & $\begin{array}{l}\text { Spraying } \\
\text { concentration }\end{array}$ & $\begin{array}{l}\text { fruit-set } \\
(\%)\end{array}$ & $\begin{array}{c}\text { Peel } \\
\text { weight } \\
\text { (g) }\end{array}$ & $\begin{array}{l}\text { Fruit } \\
\text { weight } \\
\text { (g) }\end{array}$ & $\begin{array}{c}\text { Fruit } \\
\text { diameter } \\
(\mathrm{cm})\end{array}$ & $\begin{array}{c}\text { Juice } \\
\text { ratio } \\
(\%)\end{array}$ & $\begin{array}{l}\text { T.S.S. } \\
(\%)\end{array}$ & $\begin{array}{l}\text { Juice } \\
\text { pH }\end{array}$ & $\begin{array}{c}\text { Yield } \\
\text { (kg/tree) }\end{array}$ \\
\hline \multicolumn{2}{|c|}{ Control } & 21.63 & 60.99 & 256.12 & 8.32 & 27.32 & 15.22 & 2.98 & 11.36 \\
\hline 1 & $200 \mathrm{ppm}$ & 48.08 & 81.67 & 385.67 & 11.68 & 41.43 & 16.39 & 3.39 & 16.31 \\
\hline 2 & $100 \mathrm{ppm}$ & 44.96 & 79.25 & 371.10 & 11.48 & 40.76 & 16.14 & 3.37 & 15.81 \\
\hline \multirow{2}{*}{3} & $100 \mathrm{ppm}$ & 45.79 & 81.70 & 400.14 & 11.71 & 41.75 & 16.94 & 3.43 & 17.43 \\
\hline & $200 \mathrm{ppm}$ & 51.11 & 85.35 & 408.21 & 12.37 & 45.09 & 17.73 & 3.58 & 19.83 \\
\hline \multicolumn{2}{|c|}{$\mathrm{LSD}_{5 \%}$} & 1.28 & 1.17 & 3.26 & 0.16 & 0.41 & 0.35 & 0.03 & 1.00 \\
\hline
\end{tabular}


ISSN (online): 2581-3048

The binary reaction of concentration $\mathrm{B}$ and three-time spraying outperformed the rest of all interactions, in the characteristics of the fruit-set ratio $51.11 \%$, the weight of the fruit peel $85.35 \mathrm{~g}$, the weight of the fruit $408.21 \mathrm{~g}$, the diameter of the fruit $12.37 \mathrm{~cm}$, the ratio of juice $45.09 \%$, the T.S.S. $17.73 \%$, the $\mathrm{pH} 3.58$, and the yield $19.83 \mathrm{~kg} /$ tree. These results show the importance of the interaction between the spraying concentration and the number of spraying times in improving the efficacy of the spraying with the boron.

\subsection{Effect of spraying with boron on the fruit cracking}

Foliar spraying with boron significantly decreased fruit cracking percentage compared to control, in which the percentage of cracked fruits reached $73.96 \%$. While the concentration A achieved a significant decrease compared to the control, with a percentage of cracked fruits of $21.63 \%$. The treatment of concentration B also achieved a significant reduction in the percentage of cracked fruits compared to the treatment of concentration A, with a value of $18.50 \%$, (Fig. 1).

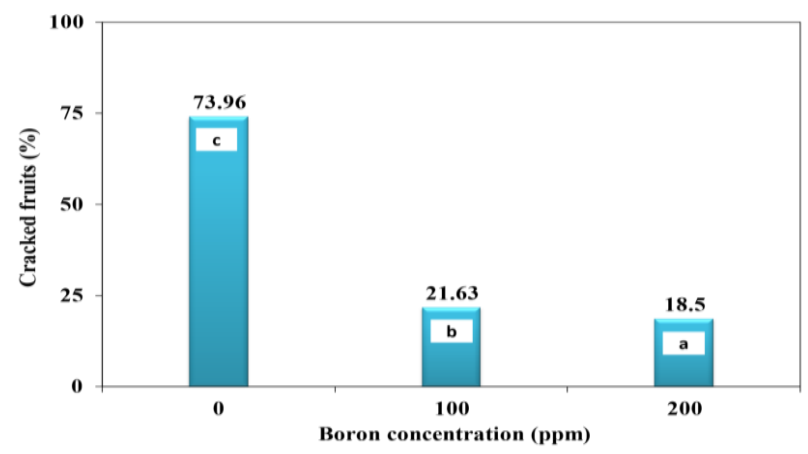

Figure 1: Effect of spraying concentration with boron on the fruit cracking $\left(\mathrm{LSD}_{5} \%=0,24\right)$

Also, increasing the number of spraying times had a significant effect in reducing the percentage of fruit cracked compared to the control. The rate of cracking in the treatments reached $73.96 \%, 26.83 \%, 19.89 \%$, and $16.28 \%$ in the control, and once, twice, and three-time spraying, respectively. The differences were significant between all treatments, (Fig. 2).

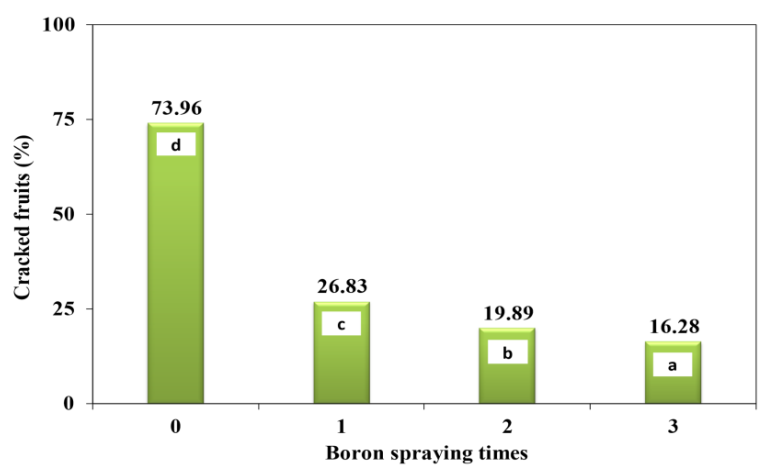

Figure 2: Effect of spraying times with boron on the fruit cracking $\left(\mathbf{L S D}_{\mathbf{5} \%}=\mathbf{0 . 3 5}\right)$
As for the interaction between spraying concentrations with boron $(0,100$, and $200 \mathrm{ppm})$ and the number of spraying times with boron $(0,1,2$, and 3 times), the effect was significant in reducing the percentage of fruit cracking of the French pomegranate variety compared to the control whit a ratio of cracking $73.96 \%$.

The binary reaction of concentration $\mathrm{B}$ with three-time spraying outperformed the rest of the interactions by $27.56 \%$, followed by the interaction of concentration $\mathrm{B}$ with twice spraying by $32.83 \%$, followed by the interaction of concentration A with three-time spraying by $33.56 \%$, then the interaction of concentration A with twice spraying by 42.64 , then concentration B with the once spraying by $46.43 \%$, then finally, the reaction of concentration A with once spraying by $47.22 \%$. The differences were significant between all these reactions (Fig. 3).

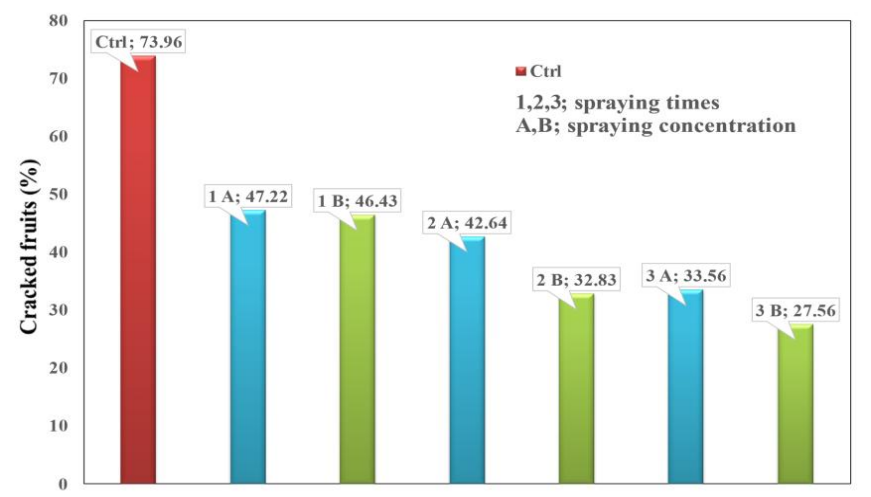

Figure 3: Effect of interaction between the spraying concentration and spraying times with boron on the fruit cracking $\left(\operatorname{LSD}_{5 \%}=\mathbf{0 , 2 6}\right)$

Our results are consistent with many studies that have shown the importance of foliar spraying with boron in reducing the percentage of fruit cracking of pomegranate. Where Abdel-Aziz et al., (2001) showed that spraying pomegranate trees four-time with boron, singly or mixed with potassium sulfate or calcium chloride, led to a reduction in the percentage of fruit cracking. Also, Kuldeep-Khatri et al., (2001) confirmed that foliar spraying with boron for JodhpurRed pomegranate variety, at a concentration of $0.2 \%$ after 15 and 30 days of fruit-set, led to a significant reduction in the percentage of fruit cracking.

The effect of boron in reducing the percentage of fruit cracking is mainly attributed to its important role in expanding cell walls by building cellulose and pectin in the cell walls of cortex cells as well as enhancing in dole acetic acid (IAA) and water absorption (Yagoden, 1990). In addition to the role of boron in activating some enzymes, which are necessary for meristematic tissues as well as for the normal development of conductive tissues (Kuldeep-Khatri et al., 2001; Sharma and Belsare, 2009; Yilmaz and Ozguven, 2009). 
ISSN (online): 2581-3048

Volume 5, Issue 3, pp 11-18, March-2021

https://doi.org/10.47001/IRJIET/2021.503003

\section{CONCLUSIONS}

1. All spraying treatments with boron outperformed control treatments in most of the studied characteristics (early flowering and ripening time, increasing the percentage of fruit-set, improving the quality characteristics of the fruits, increasing the yield).

2. The increase in the spray concentration with the boron led to a significant increase in the productivity compared to the control, as the increase was $140.49 \%$ and $88.161 \%$ in the treatments of concentrations of $100 \mathrm{ppm}$ and $200 \mathrm{ppm}$, respectively.

3. The increase in the number of spraying with the boron led to a significant increase in the productivity compared to the control, as the increase amounted to $133.27 \%, 149.47 \%$, and $159.95 \%$ in the treatments of once, twice, and three-time spraying, respectively.

4. The increase of the spraying concentration with the boron achieved a reduction in the percentage of fruit cracking compared to the control. The percentage of fruit cracking was $21.63 \%, 18.50 \%$ in the concentration treatments of $100 \mathrm{ppm}$ and $200 \mathrm{ppm}$, respectively.

5. The increase in the number of spraying with the boron achieved a reduction in the percentage of fruit cracking compared to the control. The percentage of fruit cracking reached $26.83 \%, 19.89 \%, 16.28 \%$, in the treatments of once, twice, and three-time spraying, respectively.

\section{REFERENCES}

[1] Abd I.E.; Rahman E.I. (2010). Physiological studies on cracking phenomena of pomegranate. J. AppI. Sci. Res. 6:669-703.

[2] Abdel-Aziz F.A.; Ahmed F.F.; Mosry M.H. (2001). Relation of potassium, Calcium and Boron with productivity and fruit cracking of Manfalouty pomegranate trees. The fifth Arabian Hort. Conference, Ismailai, Egypt, March: 24-28p.

[3] Al-Imam N.M.A.A; Al-Brifkany A.-A. M.A. (2010). Effect of nitrogen fertilization and foliar application of boron on fruit set, vegetative growth and yield of Anna apple cultivar (Malus domesticaBrokh). Mesopotamia J. Agric., 38(4): 9-18p.

[4] Anonymous A. (1983). Second National workshop. Arid zone fruit Research Technology. Dec. 10-13.

[5] Arora J.S.; Singh J.R. (1972). Response of Guava (Psidium guajava L.) to boron spray. J. Jaban Soc. HortSci., 41(3): 239-244p.

[6] Bambal S.B.; Wavhal K.; Nasalkar S.D. (1991). Effect foliar application micronutrients on fruit quality and yield of pomegranate - ganesh. Maharashtra journal of Hort. 32-36p.

[7] Bankar G.J.; Prasad R.N. (1992). Performance of important pomegranate cultivars in arid region. Annals of arid Zone 31(3):181-183.

[8] Chandra R.; Suroshe S.; Sharma J.; Marathe R.A.; Meshram D.T. (2011). Pomegranate growing manual. NRS on pomegranate, Solapur. 1-58.

[9] Draie R, Aboras A. (2021a). Effect of Irrigation on Cracking of Pomegranate Fruits (French Variety). IRJIET, 5(2): 24-33. Article DOI: https://doi.org/10.47001/IRJIET/2021.502005

[10] Draie R, Ali Aboras A. (2021b). Effect of Foliar Spraying with Gibberellic Acid on Fruit Cracking of Pomegranate (Punica granatum L.). IRJIET, 5(2): 53-62. Article DOI: https://doi.org/10.47001/IRJIET/2021.502009

[11] Dube S.D.; Ram C.B. (1970). Control of fruit cracking in pears Curr. Sci. 39(19): 447-556p.

[12] El-Khawaga A.S. (2007). Reduction in fruit cracking in manfaluty pomegranate following a foliar application with paclobutrazol and zinc sulphate. Journal of Applied Sciences Research 3(9): 837840p.

[13] El-Sayed O.M.; El-Gammal O.H.M.; Salama A.S.M. (2014). Effect of proline and tryptophan amino acids on yield and fruit quality of Manfalouty pomegranate variety. Scientia Hort. 169:1-5.

[14] Fayed T.A. (2010). Effect of compost tea and some antioxidant applications on leaf chemical constituents, yield and fruit quality of pomegranate. World J. Agric. Sci., 6(4): 402-411.

[15] Finkel T.; Holbrook N.J. (2000). Oxidants, oxidative stress and the biology of ageing. Nature 408:239-247.

[16] Galindo A.; Rodriguez P.; Gollado-Gonzalez J.; Cruz Z.; Torrecillas E.; Ondono S.; Corell M.; Moriana A.; Torrecillas A. (2014). Rainfall intensifies fruit peel cracking in water stressed pomegranate trees. Agric. Meteorol. 194:29-35.

[17] Gharesheikhbayat R. (2006). Anatomical study of fruit cracking in pomegranate c.v. Malas-e-Torsh. PajoheshSazandegy 69:10-14.

[18] Hoda A.K.; Hoda S.H.A. (2013). Cracking and fruit quality of pomegranate (Punica granatum L.) as affected by pre-harvest sprays of some growth regulators and mineral nutrients. J. Hortic. Sci. Ornamental plants 5:71-76.

[19] Khadivi-Khub A. (2014). Physiological and genetic factors influencing fruit cracking. Acta physiol. Plant. 37:1-14.

[20] Khalil H.A.; Aly H.S. (2013). Cracking and fruit quality of Pomegranate (Punica granatum L.) as 
ISSN (online): 2581-3048

affected by pre-harvest sprays of some growth regulators and mineral nutrients. J. Hortic. Sci. Ornam plants 5:71-76.

[21] Khan I.; Misra R.S.; Srivastava R.P. (1974). Effect of plant growth regulators on fruit drop, size and quality of litchi c.v. Rose scented. Prog. Hort. 8(2): 61-69.

[22] Kuldeep-Khatri K.; Joon M.S.; Sihag R.P. (2001). Effect of micronutrients and growth regulators on premature cracking of pomegranate var. Jodhpur red. Haryana journal of Hort. Sciences: 207-208.

[23] Malhotra V.K.; Khajuria H.N.; Jawanda J.S. (1983). Studies on physio-chemical characteristics. 1physical characteristics. Punjab Hort. J. 23: 153-157.

[24] Michra R.S.; Khan I. (1981). Effect 2,4,5,T and micronutrient on fruit size cracking maturity quality litchi cv. Ross scental. Prpgressive Hort. 13(3-4): 8790.

[25] Pal R.K.; Singh N.V.; Maity A. (2017). Pomegranate fruit cracking in dryland farming curr. Sci. 112: 896897.

[26] Pant T. (1976). Fruit cracking in pomegranate (Punica granatum L.) in variety Judipuri. Udyanika, Hort. 48(2): 29-35.

[27] Panwar S.; Desair U.T.; Chouduhary S.M. (1994). Effect of pruning on physiological disorder in pomegranate. Annals of Arid Zone 33:83-84.

[28] Perica S.; Bellaloui N.; Greve C.; Hu H.; Brown P.H. (2001). Boron transport and soluble carbohydrate concentration in Olive. Hort Science 126: 291-296.

[29] Prasad R.N.; Bankar G.J.; Vashishtha B.B. (2003). Effect of drip irrigation on growth, yield and quality of pomegranate in arid region. Indian J. Hort. 60:140-142.

[30] Saad F.A.; Shaheen M.A.; Tawfik H.A. (1988). Anatomical stydy cracking pomegranate fruit. Alexandria Journal of Agri. Research, 33(1):155166.

[31] Saei H.; Sharifanni M.M.; Dehghanic A.; Esmaeil S.; Vahid A. (2014). Description of biomechanical forces and physiology parameters of fruit cracking in pomegranate. Scientia Hortic. 178:224-230.
https://doi.org/10.47001/IRJIET/2021.503003

[32] Schrader L.; Zhang J.; Sun J. (2002). Environmental Stresses that cause sunburn of apple. XXVI. International Horticultural congress \& Exhibition, Toronto 11:397-405.

[33] Shaheen S.A.A. (1995). Effect of foliar sprays of some nutrients on flowering and fruiting of olive trees. M. SC. Thesis. Fac. of Agric. Cairo unir, 122p.

[34] Sharma N.; Belsare C. (2009). Effect of plant bioregulators and nutrients on fruit cracking and quality in pomegranate (Punica granatum L.) "G-137" in Himachal Pradesh. Acta Hortic. 890: 613-617.

[35] Shulman S.; Fainberstein L.; Lavee S. (1984). Pomegranate fruit development and maturation. J. Hortic. Sci. 59:265-282.

[36] Singh A. (1980). Fruit physiology and production. Kalyani publishers, New Delhi: 383-385.

[37] Singh D.B.; Kingsly A.R.P.; Jain R.K. (2006). Controlling fruit cracking in pomegranate. Indian Hort. 51(1): 14-32.

[38] Singh S.; Krishnamurthi S.; Katya L. (1967). Fruit culture in India.ICaR:189-196.

[39] Singh S.P. (1995). Pomegranate in commercial fruits. pp. kalyani publisher, Ludhiana: 225-233.

[40] Vossen P.; Devarenne A. (2006) - Fertility management for oil olives. First press newsletter of olive oil production and evaluation, 1(3): 122-134.

[41] Wojcik P.; Cieslinski G.; Mika A. (1999). Apple yield and fruit quality an influence by boron applications. J. Plant Nutrition, 22(9):1365-1377.

[42] Yagoden B.A. (1990). Agriculture chemistry. Mir Publishers, Moscow, 278-281.

[43] Yazici K.; Kaynak L. (2006). Effect air temperature relative humidity solar radiation fruit surface temperatures sunburn damage pomegranate Punica granatum L. c.v. Hicaznar. Acta. Hort. 181-186.

[44] Yilmaz C.; Ozguven A.I. (2009). The effect of some plant nutrients gibberellic acid and pinolene treatments on the yield, fruit quality and cracking in pomegranate cation anne. Acta. Hort. 205-212.

\section{Citation of this Article:}

Dr. Rida DRAIE, Ali ABORAS, "Impact of Concentration and Foliar Spraying Times Number with Boron on Pomegranate Fruit Cracking" Published in International Research Journal of Innovations in Engineering and Technology - IRJIET, Volume 5, Issue 3, pp 11-18, March 2021. Article DOI https://doi.org/10.47001/IRJIET/2021.503003 